Review

\title{
Ecosystem-Based Adaptation to Climate Change in Caribbean Small Island Developing States: Integrating Local and External Knowledge
}

\author{
Jessica Mercer ${ }^{1}$, Ilan Kelman ${ }^{2}$, Björn Alfthan ${ }^{3, *}$ and Tiina Kurvits ${ }^{4}$ \\ 133 Gravel Close, Downton, Salisbury, SP5 3JQ Wiltshire, UK; \\ E-Mail: jessica-mercer@hotmail.com \\ 2 Center for International Climate and Environmental Research (CICERO), P.O. Box 1129, Blindern, \\ N-0138 Oslo, Norway; E-Mail: ilan_kelman@hotmail.com \\ 3 UNEP/GRID-Arendal, Postboks 183, N-4802 Arendal, Norway \\ 4 UNEP/GRID-Arendal, 360 Albert Street, Suite 1710, Ottawa, ON K1R 7X7, Canada; \\ E-Mail: Tiina.Kurvits@grida.no \\ * Author to whom correspondence should be addressed: E-Mail: Bjorn.Alfthan@grida.no; \\ Tel.: +47-9073-4432; Fax: +47-3703-5050.
}

Received: 12 July 2012; in revised form: 6 August 2012 / Accepted: 10 August 2012 /

Published: 22 August 2012

\begin{abstract}
Caribbean Small Island Developing States (SIDS) are vulnerable to climate change impacts including sea level rise, invasive species, ocean acidification, changes in rainfall patterns, increased temperatures, and changing hazard regimes including hurricanes, floods and drought. Given high dependencies in Caribbean SIDS on natural resources for livelihoods, a focus on ecosystems and their interaction with people is essential for climate change adaptation. Increasingly, ecosystem-based adaptation (EbA) approaches are being highlighted as an approach to address climate change impacts. Specifically, EbA encourages the use of local and external knowledge about ecosystems to identify climate change adaptation approaches. This paper critically reviews EbA in Caribbean SIDS, focusing on the need to integrate local and external knowledge. An analysis of current EbA in the Caribbean is undertaken alongside a review of methodologies used to integrate local and external expertise for EbA. Finally key gaps, lessons learnt and suggested ways forward for EbA in Caribbean SIDS and potentially further afield are identified.
\end{abstract}


Keywords: adaptation; Caribbean; climate change; ecosystem; local knowledge; Small Island Developing States

\section{Introduction}

Small Island Developing States (SIDS) are a grouping of tropical island states which have banded together under the United Nations to address common sustainability challenges [1]. The vulnerability of SIDS to climate change impacts has been well documented and discussed in recent decades [2-4]. The Caribbean region is no exception, with Caribbean SIDS vulnerable to a wide range of climate change impacts including sea level rise, invasive species, ocean acidification, changes in rainfall patterns, increased temperatures, and changing hazard regimes including hurricanes, floods and drought $[5,6]$. Ecosystem-based adaptation (EbA) has been highlighted as one approach to address declines in ecosystem health and enable sustainable adaptation to climate change [7].

This paper critically reviews the use of EbA approaches in Caribbean SIDS with particular attention upon methodologies used to integrate local and external knowledge to address climate change impacts. The importance is because local knowledge tends to be neglected, in particular because it is often viewed by locals and non-locals as being backward or irrelevant in the modern world, compared to external (usually technology-based) knowledge which is seen as being modern and representing the future. Even when locals wish to preserve their own knowledge, external lack of respect for local knowledge can mean that local views and ideas are disrespected and not included in development work.

That is not claiming that local knowledge is perfect and should dominate local decision-making. Instead, seeking a balance between local and external views is essential to achieve EbA. As such, this paper identifies key gaps, lessons learnt and suggested ways forward for integrating local and external knowledge within EbA in Caribbean SIDS. That contributes to providing policy and action advice for a region requesting support to implement formally EbA techniques that have long assisted Caribbean peoples with their livelihoods.

\section{Ecosystem-Based Adaptation}

The Millennium Ecosystem Assessment (MEA) outlines a decline in worldwide ecosystem health, thereby threatening the provision of ecosystem services [8]. Degradation of ecosystems and declines in ecosystem services will reduce people's ability to adapt to and cope with, existing and anticipated climate change impacts, and threaten long term sustainability [9]. For example, an estimated one-third of Caribbean coral reef ecosystems are under threat from coastal development, and sediment and pollution from inland sources. $60 \%$ of reefs are threatened by overfishing, whilst marine based threats to coral reefs e.g., from shipping, ineffective management of protected areas, diseases and warming sea temperatures are widespread across the Caribbean [10]. In 2000, it was estimated that Caribbean coral reefs provided goods and services with an annual net economic value estimated at between US\$3.1 billion and US\$4.6 billion from fisheries, dive tourism and shoreline protection services [10]. Declines in coral reef ecosystem health would result in significant economic losses, particularly in 
Caribbean coastal areas through loss of fishing livelihoods, malnutrition due to lack of protein, the loss of tourism revenues and increased coastal erosion [10].

EbA is seen as an important approach for tackling these challenges. EbA is defined as "an approach that builds resilience and reduces the vulnerability of local communities to climate change...EbA integrates sustainable use of biodiversity and ecosystem services in a comprehensive adaptation strategy" [11] (see also [9]). The phrase EbA is relatively recent, with the terminology largely absent within relevant literature prior to 2009, although earlier uses of the phrase have been identified in, for instance, 2004 [12] and 2005 [13]. The International Union for Conservation of Nature (IUCN), currently a key advocate and player in the field of EbA, prior to 2009 in their 'Caribbean Work Program 2009-2012' referred to 'ecosystem management' and not 'EbA' [14].

Previously (except for the few early uses of the phrase outlined above), key phrases used included 'ecosystem-based management' and 'ecosystem management' [15] which 'reflect three common origins...protected areas, cooperative management, and management responses to complex demands and pressures". Post-2008, use of the phrase EbA and the development of EbA approaches have expanded considerably (see [16] for a database of EbA examples), yet also with a narrowing that deliberately focuses on climate change. Reflecting this development, in June 2011 a group of international, mostly conservation organisations drafted some key principles for ecosystem-based approaches to adaptation including [17];

(1) EbA promotes multi-sectoral approaches;

(2) EbA operates at multiple geographic scales;

(3) EbA integrates flexible management structures that enable adaptive management;

(4) EbA minimizes trade-offs and maximizes benefits with development and conservation goals to avoid unintended negative social and environmental impacts;

(5) EbA is based on the best available science and local knowledge, and should foster knowledge generation and diffusion;

(6) $\mathrm{EbA}$ is about promoting resilient ecosystems and using nature-based solutions to provide benefits to people, especially the most vulnerable;

(7) EbA must be participatory, transparent, accountable, and culturally appropriate, while actively embracing equity and gender issues.

The call for integrating local knowledge with scientific knowledge is significant (point 5 above). Local people can hold vast amounts of information and experience of their environment built up over countless generations (see [18] for more information on the need to integrate local and external knowledge). Building upon local knowledge and non-infrastructural, or "soft" approaches is potentially more cost effective and accessible by poor and/or rural communities than measures based on purely external interventions or those highlighting engineering infrastructure [19-21]. This is especially important for smaller, more isolated communities, such as Caribbean SIDS, which might not have the population size or resources to continually build and maintain extensive infrastructure [22-24]. Healthy ecosystems and their services play a vital role in reducing climate risk and providing opportunities for sustainable development and livelihoods.

Local knowledge is also often referred to as 'indigenous knowledge', 'traditional knowledge', 'indigenous technical knowledge', 'traditional environmental knowledge' or 'folk knowledge' [25]. 
Throughout this paper the term 'local knowledge' is used as it better defines knowledge that has evolved within (inside) a specific community or area, but that has potentially incorporated or been shaped by outside knowledge in its continuous evolution [18]. In parallel, external knowledge is generally understood to involve technology or specific approaches developed outside a community. In many cases this knowledge has been empirically proven or developed using methods that are judged by scientific 'experts' of the time to be rigorous and in accordance with accepted practice [18].

\section{Ecosystem-Based Adaptation and Caribbean SIDS}

Inhabited by approximately 40 million people, the Caribbean region is known for its natural beauty and unique cultures. The people of this region are heavily reliant upon the natural resource base for their livelihoods including fisheries, forestry, agriculture, mining and tourism [26]. Caribbean SIDS are diverse, ranging from small island tropical countries with economies dependent on agriculture and tourism such as St. Lucia, to larger less economically developed and more populated countries such as Haiti.

Despite this diversity, climate change significantly impacts all Caribbean SIDS, especially given the dependence on natural resources for many livelihoods, including most tourism-based livelihoods. Freshwater availability is of particular concern especially in light of climate change and increased population levels [27]. If greenhouse gas emissions continue unabated, the cost to Caribbean islands in terms of increased hurricane damage, loss of tourism revenue and infrastructure damage is projected to reach $\$ 22$ billion by 2050 and $\$ 46$ billion by 2100 or $10 \%$ and $22 \%$ of the current Caribbean economy [28].

Whilst negotiations continue at the international level to reduce greenhouse gas emissions, the Caribbean community (CARICOM) recognises the need for urgent action to adapt to existing and anticipated climate change impacts [26]. Given the Caribbean's fragile natural resource base and the high dependence on natural resources there has been an increased focus upon terrestrial, coastal and marine ecosystems and their interaction with people for adaptation to climate change [29]. With 70\% of the world's poor living in rural areas, a focus upon ecosystems and their importance for sustainable development is paramount [30]. Ecosystems and the services they provide (e.g., food, shelter, risk reduction, freshwater supply, medicines, and climate regulation) are essential components of life support on Earth [31]. They underpin much past and a good proportion of existing livelihood activity (off-shore financing is an example of current non-ecosystem livelihood in Caribbean SIDS) and are essential to achieving long-term sustainable livelihoods in the future [31,32].

In a recent review of current and planned adaptation action in the Caribbean many actions emphasised the need for an ecosystem-based approach to adaptation, specifically through integrated coastal zone management and integrated watershed management [33]. The review outlined that "there is clear national and regional recognition that ecosystem services can greatly reduce adaptation costs while providing numerous co-benefits (i.e., mangroves and reefs protect shorelines from erosion and supply fisheries; forests mitigate landslides, flooding and drought)" [33]. However, the majority of this action centred upon coastal ecosystems at a regional level, as opposed to the full range of diverse ecosystems in existence within Caribbean SIDS. This is especially important given the tight linkages between ecosystems in SIDS. In addition, no reference was given to the need to integrate local and external knowledge to develop appropriate context specific solutions. 
That has resulted in large gaps with regard to EbA approaches to climate change adaptation (CCA) in Caribbean SIDS. Yet, as outlined by the United Nations Framework Convention on Climate Change (UNFCCC), EbA approaches are identified as widely applicable at different spatial and temporal scales, and across multiple sectors whilst incorporating different knowledge bases [34]. This section assesses to what extent EbA approaches using local and external knowledge are incorporated into CCA activities within Caribbean SIDS at regional, national and local levels. It builds upon and supplements the review undertaken by Medeiros et al. [33] which focused on the SIDS of Antigua and Barbuda, Barbados, Cuba, Dominica, Dominican Republic, Grenada, Haiti, Jamaica, Saint Kitts and Nevis, Saint Lucia, Saint Vincent and the Grenadines, and Trinidad and Tobago.

\subsection{Regional Level Action in Caribbean Small Island Developing States}

There are a large number of CCA initiatives occurring at the regional level in Caribbean SIDS [33]. This is in recognition of the need for regional cooperation in terms of adaptation action given similarities in climate change vulnerabilities across the region. Since 2000 CARICOM has implemented a series of projects to help understand the region's vulnerability to climate change, build capacity, develop and implement adaptation plans and mainstream adaptation throughout different sectors. The projects included: "Caribbean Planning for Adaptation to Climate Change" (1997-2001); "Adaptation to Climate Change in the Caribbean" (2001-2004); "Mainstreaming Adaptation to Climate Change" (MACC) (2004-2009); and the "Special Program on Adaptation to Climate Change: Implementation of adaptation measures in coastal zones" (SPACC) (2007-2011). The Caribbean Community Climate Change Centre ( $\mathrm{CCCC}$ ) emerged from these initiatives and now serves as the official repository and clearing house for regional climate change data, providing climate change-related policy advice and guidelines to CARICOM Member States.

A regional roadmap for adaptation action in the Caribbean was developed in 2009 (to 2015) [35]. This identified a number of strategic goals for the region including the need to address climate change impacts on coastal and marine ecosystems in particular. However, regional initiatives to date have focused on capacity building, preparation of national climate change policies, provision of technical assistance, climate information and monitoring, assessments and research, education and communication, and policy formation. These initiatives have made essential contributions to government capacity building, although this is currently not translating into on the ground action integrating local and external expertise for ecosystem-based approaches to adaptation [33]. Those programs such as MACC and SPACC which have translated into action at the local level have been significantly narrow in their activity with particular attention paid to coastal ecosystems. Integrated Coastal (Zone) Management (IC(Z)M) and Marine Protected Areas (MPAs) have received significant attention, including amongst Caribbean SIDS such as Jamaica and St. Lucia [36].

One significant regional level project, the 'Pilot Project for Climate Resilience' (PPCR) [37] aims to pilot and demonstrate ways in which climate risk and resilience may be integrated into core development planning and implementation. The first component of the project continues the theme of regional capacity building, monitoring and research. The significance of ecosystems and ecosystem management are highlighted throughout the PPCR, although ecosystems including wetlands, forests and off shore marine ecosystems are neglected with the majority of attention diverted to coastal ecosystems. Key principles of EbA including the need to consult local communities and build upon 
local knowledge are also hardly reflected. The second component involves pilot initiatives at the national level.

\subsection{National Level Action in Caribbean Small Island Developing States}

At the national level the PPCR is assisting Dominica, Grenada, Haiti, Jamaica, Saint Lucia, and Saint Vincent and the Grenadines to develop a Strategic Program for Climate Resilience (SPCR). Here, as compared to the regional level, further consideration is being given to the importance of ecosystem management and in some cases the integration of local and external knowledge, albeit focused upon coastal ecosystems. St Lucia's SPCR for example refers to the need to use traditional knowledge, yet no clear links are made between the objectives of ecosystem management and the need to use traditional knowledge and/or integrate this with external knowledge to build community resilience [38].

St Lucia's SPCR, however, is an exception. Caribbean SIDS have outlined national adaptation needs and measures within their National Communications to the UNFCCC. These documents reflect a strong focus upon the importance of ecosystems for CCA but do not specifically discuss EbA and the need to integrate local and external knowledge. Similar to regional level action, the attention of national level action in Caribbean SIDS has been mainly on coastal ecosystems. Limited consideration is given to the diverse range of other ecosystems in existence within and across Caribbean SIDS and/or the relevance and applicability of local knowledge across this diverse range of ecosystems [33].

The majority of Caribbean SIDS have directed their CCA efforts through CARICOM and are involved in multi-country initiatives to address climate change impacts [33]. Initial attention was upon the integration or mainstreaming of CCA into national development policy and plans, in addition to education and capacity building activities. Increasingly, donor support to CCA activity at the national level within Caribbean SIDS is centred upon the implementation of identified CCA strategies.

In Jamaica for example, the European Union (EU) has been working with the Planning Institute of Jamaica (PIOJ) and the United Nations Environment Programme (UNEP) to implement a CCA and disaster risk reduction (DRR) project including watershed rehabilitation and improved coastal ecosystem management [39]. Similarly, in Grenada, the German government is supporting the implementation of an integrated approach to water and coastal resource management. Whilst both of these projects visibly highlight ecosystems and CCA, neither project specifically mentions EbA nor integration of local and external knowledge for ecosystem-based adaptation approaches to CCA.

In a review of projects explicitly supporting CCA activity, Medeiros et al. [33] outline a comparison of adaptation action at the policy and program level for specific Caribbean SIDS (see Table 1). Whilst this was a rapid desk-based review and the adaptation environment within the Caribbean region is constantly evolving, the majority of Caribbean SIDS are implementing CCA initiatives through wider regional level action. This is as opposed to more context specific national and local level actions which have the potential to build upon locally based knowledge in addition to external, scientific knowledge. The development of national projects linked with local level action using both local and external knowledge will only contribute to the development of appropriate, context specific CCA incorporating EbA approaches and their direct implementation. 
Table 1. Comparison of adaptation action at the policy and program level for select Caribbean Small Island Developing States (SIDS) (as of May 2012) based on [33].

\begin{tabular}{|c|c|c|c|c|c|c|}
\hline & \multicolumn{3}{|c|}{ Policy Action } & \multicolumn{3}{|c|}{ Participation in Projects/Programs } \\
\hline & $\begin{array}{c}\text { 1st } \\
\text { National } \\
\text { Communication }\end{array}$ & $\begin{array}{c}\text { 2nd } \\
\text { National } \\
\text { Communication }\end{array}$ & $\begin{array}{c}\text { National } \\
\text { Strategy/ } \\
\text { Plan } \\
\end{array}$ & National & Multicountry & Total \\
\hline $\begin{array}{l}\text { Antigua \& } \\
\text { Barbuda }\end{array}$ & 2001 & 2011 & & 0 & 5 & 5 \\
\hline Barbados & 2001 & $\begin{array}{c}\text { Under } \\
\text { development }\end{array}$ & & 2 & 5 & 7 \\
\hline Cuba & 2001 & 2001 & 2007 & 1 & 5 & 6 \\
\hline Dominica & 2001 & $\begin{array}{c}\text { Under } \\
\text { development }\end{array}$ & & 0 & 6 & 6 \\
\hline $\begin{array}{l}\text { Dominican } \\
\text { Republic }\end{array}$ & 2003 & 2009 & NAPA (2008) & 1 & 8 & 9 \\
\hline Grenada & 2000 & $\begin{array}{c}\text { Under } \\
\text { development }\end{array}$ & $\begin{array}{c}\text { National Climate } \\
\text { Change Policy } \\
\text { and Action Plan } \\
2007-11\end{array}$ & 0 & 7 & 7 \\
\hline Haiti & 2002 & 2002 & & 3 & 2 & 5 \\
\hline Jamaica & 2000 & 2011 & $\begin{array}{c}\text { Under } \\
\text { development }\end{array}$ & 2 & 7 & 9 \\
\hline $\begin{array}{l}\text { St Kitts \& } \\
\text { Nevis }\end{array}$ & 2001 & 2000 & & 0 & 4 & 4 \\
\hline St Lucia & 2001 & 2012 & $\begin{array}{l}\text { Climate Change } \\
\text { Adaptation Policy } \\
\text { and Strategy } \\
(2003)\end{array}$ & 0 & 7 & 7 \\
\hline $\begin{array}{l}\text { St. Vincent \& } \\
\text { the Grenadines }\end{array}$ & 2000 & $\begin{array}{c}\text { Under } \\
\text { development }\end{array}$ & $\begin{array}{l}\text { Prepared; date } \\
\text { unknown }\end{array}$ & 0 & 6 & 6 \\
\hline $\begin{array}{l}\text { Trinidad \& } \\
\text { Tobago }\end{array}$ & 2001 & $\begin{array}{c}\text { Under } \\
\text { development }\end{array}$ & $\begin{array}{c}\text { Draft Climate } \\
\text { Change Policy } \\
(2010)\end{array}$ & 0 & 3 & 3 \\
\hline
\end{tabular}

\subsection{Local Level Action in Caribbean Small Island Developing States}

There are a large number of initiatives occurring at the local level to address adaptation to climate change impacts. The majority have been or are being implemented by local and/or international non-governmental organizations (NGOs). Unlike regional and national levels, at the local level specific attention has been given to EbA approaches for climate change including the need to integrate local and external knowledge. As outlined in the introduction of this paper this movement has been mostly led by international conservation organizations such as the International Union for the Conservation of Nature (IUCN), BirdLife International, World Wide Fund for Nature (WWF) and The Nature Conservancy. 
One example of a local level EbA project comes from BirdLife International who are working with local partners in Macaya Biosphere Reserve, Haiti to conserve and reforest degraded forest ecosystems, stabilising slopes and ensuring continued drinking water supplies for local communities [40]. Another example comes from Belize where WWF is advocating, identifying, and implementing coastal management activities as part of a broader programme of activities on the health of the Mesoamerican Reef [41]. Both projects explicitly highlight CCA and are EbA, yet are important beyond EbA and climate change. In addition, both projects highlight the need to build upon local and external knowledge in the development of solutions.

In addition to projects specifically outlining EbA, many CCA initiatives at the local level address ecosystem conservation and restoration. For example, the Future Centre Trust in Barbados is involved in education and awareness as well as beach clean-ups, aiming to help tourists and locals better understand the island's ecosystems, for CCA and other sustainability endeavours. Many local projects are not well documented or publicised, so evaluating their impact and the extent to which they incorporate local and external knowledge is difficult.

\section{Methodologies for Combining Knowledge Forms for EbA}

In the larger field of DRR including CCA, the importance of local, indigenous and/or traditional knowledge has long been recognised and stressed [42-44]. Building upon local knowledge and practices, and engaging those 'at risk' is a significant component of Community-based Disaster Risk Reduction (CBDRR) and its subset of Community-based Adaptation (CBA) [43,45]. This recognises that whilst SIDS communities have suffered loss and hardship, in many instances they have displayed significant coping capacities developed over centuries to deal with societal and environmental change [46].

This local knowledge would be useful for developing EbA strategies. It is however, important not to over-romanticise local knowledge, aspects of which may also be contributing to increased vulnerability or 'mal-adaptation'. It is essential that an assessment of both local and external knowledge is undertaken in order to integrate that knowledge, either local or external to a community which best strengthens community and ecosystem resilience [18,47].

There are a number of examples worldwide demonstrating the use of local and external knowledge in relation to ecosystem management $[48,49]$. In addition, whilst not always directly focused on ecosystems per se, yet nonetheless covering aspects of ecosystems, there are large numbers of case studies outlining use of local knowledge to address climate change impacts such as in Samoa [50], Kenya [51], Uganda [52], New Zealand [53], Mongolia [54], India [55] and Mexico [56]. The SIDS-specific case studies which directly invoke EbA are mostly found within reports from conservation organisations with IUCN, The Nature Conservancy, BirdLife International, Conservation International and WWF being key advocates of EbA for the Caribbean [11]. Table 2 outlines some examples of specific SIDS case studies from the Caribbean and beyond which use local and external expertise for $\mathrm{EbA}$ and/or CCA. 
Table 2. Examples of SIDS case studies linking local and external expertise with links to EbA (Caribbean examples highlighted).

\begin{tabular}{|c|c|c|c|}
\hline Date & SIDS & Study & Comments \\
\hline 2010 & Haiti [40] & $\begin{array}{l}\text { Macaya Biosphere } \\
\text { Reserve. }\end{array}$ & $\begin{array}{l}\text { - EbA approach. } \\
\text { - Builds upon local knowledge. }\end{array}$ \\
\hline 2009 & Belize [41] & $\begin{array}{l}\text { Protection of } \\
\text { Mesoamerican Reef. }\end{array}$ & $\begin{array}{l}\text { - EbA approach. } \\
\text { - Incorporates local knowledge. }\end{array}$ \\
\hline 2010 & Samoa [57] & $\begin{array}{l}\text { Reducing climate } \\
\text { vulnerability of coastal } \\
\text { communities. }\end{array}$ & $\begin{array}{l}\text { - No specific focus on EbA. } \\
\text { - Addresses climate change and other hazards } \\
\text { in coastal communities. } \\
\text { - Integrating local and outside expertise. }\end{array}$ \\
\hline 2012 & Tonga [58] & $\begin{array}{l}\text { Investigating local } \\
\text { initiatives on EbA. }\end{array}$ & $\begin{array}{l}\text { - Specific focus on EbA (and CBA). } \\
\text { - Provides lessons from local initiatives } \\
\text { on EbA. } \\
\text { - Stresses the importance of local knowledge. }\end{array}$ \\
\hline $\begin{array}{l}2005- \\
2012\end{array}$ & Fiji [59] & $\begin{array}{l}\text { Development of a ridge } \\
\text { to reef protected area in } \\
\text { Kubulau District, Fiji. }\end{array}$ & $\begin{array}{l}\text { - Specific EbA focused approach. } \\
\text { - Integrates flexible management structures } \\
\text { and uses nature based solutions. } \\
\text { - Incorporation of local and traditional } \\
\text { knowledge. } \\
\text { - Development of Kubulau } \\
\text { Ecosystem-based management plan (EBM). }\end{array}$ \\
\hline 2009 & $\begin{array}{l}\text { Papua New } \\
\text { Guinea [16] }\end{array}$ & $\begin{array}{l}\text { Kimbe Bay: Resilient } \\
\text { network of marine } \\
\text { protected areas. }\end{array}$ & $\begin{array}{l}\text { - EbA approach. } \\
\text { - Involves community consultation although } \\
\text { no particular stress on local knowledge. }\end{array}$ \\
\hline
\end{tabular}

One of the key principles of $\mathrm{EbA}$ is combining different knowledge forms for local implementation [17,60]. Despite this, there is no single identified systematic way of integrating local and external knowledge for EbA, specifically in SIDS given their vulnerability to climate change impacts [61]. For the most part the projects in Table 2, whilst outlining a need to integrate local and external knowledge, do not outline specific methods or 'ways of doing so' beyond stakeholder consultation and discussion.

Through a desk-based literature review ten methodologies have been identified within the wider field of DRR and CCA which specifically address knowledge integration and could potentially be viable for EbA. These methodologies fall into two specific categories; (a) networks or consortia (for which two examples are given) and (b) participatory planning and techniques (for which eight examples are given).

There are a large number of networks and consortia addressing climate change and risk reduction issues, but there are few which focus on the need to integrate local and external expertise, especially for SIDS. One such network developed and established in 2005 is a consortium of organisations, researchers and policy makers from the Arctic and SIDS called 'Many Strong Voices' (MSV) [62]. MSV aims to advance mutual learning and exchange of knowledge, research and expertise on climate change within and between the Arctic and SIDS. The strengths of MSV include its community-driven nature, ensuring Arctic and SIDS voices are heard at international, national and local levels; the 
accessibility of forums to share and exchange knowledge; contributions to local organisational capacity building over extended time periods; engagement in policy-relevant integrated research incorporating local and external knowledge; and a recognition of linkages with natural resource management alongside the need to maintain healthy, functioning ecosystems [3]. MSV depends on interaction and facilitation of key member organisations to ensure local voices are heard. Furthermore, given its global nature it relies on a virtual network and electronic communication, not always accessible to SIDS and Arctic communities.

Addressing these limitations, further lessons for Caribbean SIDS could be drawn from the Arctic region's 'Exchange for Local Observations and Knowledge of the Arctic' (ELOKA). Similarly to MSV, although centred upon another region, the goal of ELOKA $[63,64]$ is to facilitate the collection, preservation, exchange, and use of local observations and Arctic knowledge by providing data management and user support, and to foster collaboration between local and international researchers. Local knowledge and observations are documented in the language of choice by knowledge holders so nothing is lost 'in translation' and different methods are used for collection, e.g., drama, video, and photos. This ensures local knowledge remains within communities and all details are preserved, yet the use of different tools and methods often results in the production of many different but interrelated data sets. For example, a single observation/knowledge documentation could produce any or all of: text documents, ethical research documents, tables, works of art, articles of clothing, audio and video recordings, transcripts of records, photographs, animations, maps, Global Positioning System (GPS) tracks, local gazetteers, local dictionaries and other linguistic materials and local weather station data. This is in addition to complementary scientific information including topographic maps and satellite images.

Lessons could be learnt from MSV and ELOKA to create a 'sub-network' for Caribbean SIDS building upon local Caribbean knowledge and external expertise for EbA, and creating context specific tools and resources. Given a climate change coordination body, the Caribbean Community Climate Change Centre (CCCCC) already exists there is opportunity to directly engage local communities to build creative partnerships for EbA building upon lessons from MSV and ELOKA. In doing so, further thought needs to be given to the documentation and use of local knowledge for EbA.

ELOKA, for example, documents the local knowledge in depth but struggles to ensure this information is available to a wide variety of end users including local community members given each user group has different access needs and requires information in different formats. However, caution is needed in presenting local knowledge in the absence of its local and cultural context because it may not be applicable to all other situations [65]. This lends further support to the need for a regional Caribbean network hosting local and external knowledge for EbA. Significant technical and methodological support is required to establish effective and appropriate means of recording, storing and managing data and information resulting from the documentation of local knowledge and to link this information in a way that is intuitive and flexible with scientific information. As with MSV and ELOKA, the engagement between outside researchers, experts and community members needs to be sustained over extended time periods to ensure sustainability.

Additional methodologies for integrating local and external expertise revolve around participatory planning techniques. Eight specific methodologies are identified (see also Table 3), reflecting the 
integration of local and external expertise for CCA and/or DRR, therefore being potentially viable for EbA. These are:

1. Risk and Vulnerability Assessment Methodology (RiVAMP) [66].

2. Adaptive Co-Management and Cooperative Research [67-69].

3. Participatory 3-D Mapping (P3DM) [70].

4. Participatory Tools [71].

5. Participatory Planning Processes [57].

6. Participatory Geographical Information Systems (PGIS) [72].

7. A Process Framework for integrating indigenous and scientific knowledge [73,74].

8. Scenario Planning [75].

Of these methodologies, RiVAMP was the only one developed specifically in a Caribbean SIDS (Jamaica) for EbA. RiVAMP was established to design an assessment tool accounting for ecosystem and climate change factors within disaster risk and vulnerability analysis [66]. The project aimed to assist national and local government decision makers in evaluating their development options effectively by recognising the role of ecosystems in reducing risk and adapting to climate change impacts. The targeted end users for RiVAMP were national and local level government decision makers, whereas for EbA the stress is on the need to involve 'users of ecosystems' and 'local communities' in local level decision making. The RiVAMP process has not appeared to strengthen the capacity of local community based organisations nor contribute to education to assist community members understand linkages between ecosystem restoration and conservation, and CCA.

RiVAMP, Adaptive Co-Management and Co-Research, Participatory Planning and the Process Framework are all forms of participatory planning methods within which methods including Scenario planning, Participatory Tools, P3DM and PGIS are used in attempts to reach acceptable solutions applicable to all stakeholders. The strengths and weaknesses of each of these methodologies are summarised in Table 3.

The overarching themes emerging are communication and the need to establish trust and linkages amongst wide varieties of stakeholders. That is alongside linking bottom-up and top-down actions. This is often a difficult task which needs to be sustained over long periods of time, made difficult by often short duration donor funded project periods in Caribbean SIDS. All the methodologies including the two networks outlined are consultative and encourage local level decision-making and action to address risk reduction including climate change impacts. In addition, all the methodologies recognise a need for sustainable natural resource management strategies, but this has not necessarily been connected to EbA (with the exception of RiVAMP). A need to validate local knowledge and ensure its accessibility to outside stakeholders has also been outlined although only P3DM, PGIS and to some extent ELOKA have made movements towards this.

Despite local support for the methods and their apparent advantages, there has been little in-depth analysis of them. In order to support EbA and its key principles, it is necessary to evaluate these approaches in more detail for Caribbean SIDS, identifying singular or mixed methods which would work within the Caribbean context for EbA. Taking advantage of the diversity of Caribbean SIDS would be particularly important in order to compare and contrast different sites to determine differences and similarities based on local distinctiveness. Furthermore, any local knowledge identified 
and recorded needs to be assessed for its efficacy and validity in addressing climate change impacts. In turn, external, scientific information needs to be provided in a format easily usable and understandable for local communities. That would contribute to achieving effective integration of knowledge forms to take place for EbA in Caribbean SIDS.

\section{Discussion: Gaps and Lessons Learnt}

The review of CCA initiatives in the Caribbean SIDS outlined in this paper reflects experience in using EbA. As shown in presenting these initiatives, they are currently ad hoc without much of a uniform approach across the Caribbean, either at regional, national or local levels, especially with regards to integrating local and external knowledge. Whilst it is appropriately accepted that a 'one size fits all' attitude would be inappropriate due to local distinctiveness, there could be some benefit to consolidating existing approaches for comparative purposes, to learn from each other and to identify good practices - even while recognising their contextuality. Such an approach could provide some practical guidance to help improve implementation and knowledge integration across scales within Caribbean SIDS, especially if generic principles were identified which applied to numerous, disparate case studies.

This section identifies the main gaps and lessons from the material in this paper to indicate ways forward in the conclusions.

Gap 1: EbA stresses the need to build on local knowledge, yet integrating local and external knowledge for EbA rarely occurs in practice.

A wide range of CCA activities are underway or have been completed in Caribbean SIDS. Ranging from region-wide to local initiatives, many mention 'ecosystems' in some form [33]. Nevertheless, at the regional and national levels, little reference is given specifically to EbA and the integration of local and external knowledge.

In contrast, at the local level, EbA has been applied in SIDS such as Haiti and Belize to develop appropriate context-specific options based on local and external knowledge. As increased attention is being paid to local knowledge and the need to integrate this with external knowledge by International development and conservation organisations, along with government development agencies, many local level projects implemented by these donors and their local partners stress the need to incorporate local knowledge into project activities. How that is achieved in practice is not always fully articulated, despite the methods available discussed in Section 4. These methods all entail a high degree of interaction and communication amongst the project parties, based on mutual respect, trust, and understanding for different viewpoints. The methodologies outlined are starting points, yet to facilitate the integration of different knowledge bases for $\mathrm{EbA}$, further evaluation, consolidation and development of these methodologies within SIDS would be useful.

There is a particular need to respect the cultural particularities of all communities, including Indigenous peoples, to ensure smooth implementation and local support [76]. With such principles already established in research and policy, coordination amongst stakeholders would assist in implementing them in practice, particularly with regards to the integration of local and external knowledge [77]. 
Table 3. Strengths and limitations of participatory planning methodologies integrating local and external knowledge for Climate Change Adaptation (CCA) and/or Disaster Risk Reduction (DRR).

\begin{tabular}{|c|c|c|c|}
\hline No. & Methodology & Strengths & Limitations \\
\hline \multicolumn{4}{|c|}{ Participatory Planning and Techniques } \\
\hline 2 & $\begin{array}{l}\text { Adaptive } \\
\text { Co- } \\
\text { management } \\
\text { and } \\
\text { Cooperative } \\
\text { Research } \\
\text { [67-69]. }\end{array}$ & $\begin{array}{l}\text { Emphasises group decision making accommodating diverse views } \\
\text { and shared learning [78]. } \\
>\text { Recognises that multiple sources of knowledge are critical to problem } \\
\text { solving. } \\
>\text { Emphasises trust building, institutional development and social } \\
\text { learning. } \\
>\text { Provides a process for mediating conflict and addressing power } \\
\text { dynamics [68]. } \\
>\text { Builds on culturally embedded formal and informal rules and norms } \\
\text { to form horizontal and vertical networks. } \\
>\text { Enhances the capacity of resource management organizations to } \\
\text { respond proactively to uncertainty. } \\
>\text { Can contribute to trans-generational transfer of local knowledge } \\
\text { through youth engagement [69]. } \\
>\text { Enables co-researchers to develop a shared cross-cultural } \\
\text { understanding of the research [69]. }\end{array}$ & $\begin{array}{l}\text { Creating the social and institutional space for the } \\
\text { necessary interactions is a difficult task. } \\
>\text { Requires multi level governance arrangements. } \\
\text { Formalized nature of interactions between locals and } \\
\text { government can create barriers to participation in } \\
\text { decision making. } \\
>\text { Establishing effective institutional arrangements and trust } \\
\text { takes extended periods of time. } \\
\Rightarrow \text { An in-depth governance assessment to understand society } \\
\text { dynamics and power structures is required prior to } \\
\text { implementation of adaptive co-management structures. } \\
\text { Adaptive co-management processes are slow or will fail } \\
\text { to develop unless policy environments are supportive of } \\
\text { multi-level learning networks, and, in turn, scientists and } \\
\text { others are rewarded for participating in these networks. }\end{array}$ \\
\hline
\end{tabular}


Table 3. Cont

\begin{tabular}{|c|c|c|c|}
\hline No & Methodology & Strengths & Limitations \\
\hline \multicolumn{4}{|c|}{ Participatory Planning and Techniques } \\
\hline 3 & $\begin{array}{l}\text { Participatory } \\
\text { 3-D Mapping } \\
{[70] .}\end{array}$ & $\begin{aligned} & \text { Collaborative, low-cost activity involving a wide range of } \\
& \text { stakeholders [70]. } \\
& \text { Participants are able to plot desired criteria e.g., resources, landmarks, } \\
& \text { environmental features, household occupants. This contributes to } \\
& \text { credibility of local knowledge. } \\
&>\text { Facilitates interpretation, assimilation \& understanding of } \\
& \text { geo-referenced information by making it visible and tangible [70]. } \\
&>\text { Raises local awareness of territories, provides stakeholders with } \\
& \text { powerful mediums for land use management and serves as an } \\
& \text { effective community organising tool [79]. } \\
&>\text { As maps are scaled and geo-referenced scientists are rigorously able } \\
& \text { to integrate their own knowledge with local people knowledge. }\end{aligned}$ & $\begin{array}{l}\text { Material is prepared by facilitators first, e.g., a scaled and } \\
\text { geo-referenced base map using Geographical Information } \\
\text { Systems (GIS). This means the methodology is not } \\
\text { necessarily replicable by communities who do not have } \\
\text { access to, or understand this technology. } \\
\text { If not carefully facilitated maps may be used by } \\
\text { facilitators to either replace local conceptions of territory } \\
\text { or impose their own views of the world [80]. } \\
\text { Difficult to map all dimensions of vulnerability and } \\
\text { capacity e.g., social networks. }\end{array}$ \\
\hline 4 & $\begin{array}{l}\text { Participatory } \\
\text { Tools [71]. }\end{array}$ & $\begin{array}{l}\text { Listening instead of lecturing-learning from local knowledge. } \\
\text { The emphasis is on visual techniques, theatre and story-telling as } \\
\text { opposed to written techniques. This is to ensure those who are } \\
\text { illiterate can participate and engage. } \\
>\text { Enables the verification of information using a range of } \\
\text { overlapping methods. } \\
>\text { Focuses on community strengths rather than dwelling on weaknesses. } \\
>\text { Identifies and empowers local analysts. } \\
>\text { Potentially establishes a common ground for communication which } \\
\text { demystifies science. }\end{array}$ & $\begin{array}{l}\text { There is a tendency to over-romanticise local knowledge } \\
\text { when it may not always be applicable or appropriate. } \\
\text { Community expectations are often raised. } \\
\text { Use of participatory tools can take extended periods } \\
\text { of time. } \\
>\text { Often difficult to engage outside experts in local level } \\
\text { assessments and planning-need to link with wider local } \\
\text { and national government processes. } \\
>\text { Difficult to integrate scientific knowledge and expertise } \\
\text { in terms of climate change. } \\
>\text { Whilst these techniques enable the identification of } \\
\text { knowledge they do not necessarily facilitate integration } \\
\text { and further steps need to be taken to ensure this } \\
\text { occurs [81]. }\end{array}$ \\
\hline
\end{tabular}


Table 3. Cont

\begin{tabular}{|c|c|c|c|}
\hline No & Methodology & Strengths & Limitations \\
\hline \multicolumn{4}{|c|}{ Participatory Planning and Techniques } \\
\hline 5 & $\begin{array}{l}\text { Participatory } \\
\text { Planning } \\
\text { Processes [57]. }\end{array}$ & $\begin{array}{l}\text { Enables stakeholders to appraise, analyse and address issues through } \\
\text { recognising and sharing all available knowledge in order to reach agreed } \\
\text { upon, acceptable solutions. } \\
>\text { Effective consultation can lead to high impact results [57]. } \\
>\text { Plans are formally signed and owned by government, private agencies and } \\
\text { communities with responsibilities allocated to each body - reinforces the } \\
\text { significance of 'partnership'. } \\
>\text { An integrated viewpoint can be taken—successfully linking knowledge } \\
\text { bases to address development challenges [49,57]. } \\
>\text { Can be led by local officials and community members. } \\
>\text { Visual photographs can be used to aid discussions and link local and } \\
\text { outside expertise. } \\
>\text { Blends traditional decision making systems with contemporary } \\
\text { ones—-process if flexible \& adaptive. }\end{array}$ & $\begin{array}{l}\text { Time consuming and costly to directly consult large } \\
\text { numbers of people. } \\
>\text { Increased workload on government staff. } \\
>\text { Difficult to keep all agencies involved motivated } \\
\text { throughout the lengthy process. } \\
>\text { Often there is a gender bias with a tendency for men } \\
\text { to be more outspoken and women to sit in } \\
\text { the background. } \\
>\text { Easier to implement and maintain within } \\
\text { smaller countries. }\end{array}$ \\
\hline 6 & $\begin{array}{l}\text { Participatory } \\
\text { GIS [72]. }\end{array}$ & $\begin{array}{l}\text { Provides a stimulating forum for inter-disciplinary analysis allowing } \\
\text { physical and social scientists and communities to participate in rigorous } \\
\text { evaluations of dissimilar data [82]. } \\
>\text { Able to produce maps of varied scales and content related to different } \\
\text { actor and process purposes. } \\
>\text { Helps promote more robust community decision-making. } \\
>\text { Has the potential to contribute positively to good governance by } \\
\text { improving dialogue, legitimizing and using local knowledge, generating } \\
\text { some redistribution of resource access and control rights, and enabling } \\
\text { local community groups by means of new skills training [83]. } \\
>\text { Improved transparency and visibility of relationships between } \\
\text { communities and local government. } \\
>\text { Legitimises local knowledge and enables accessibility by outside } \\
\text { stakeholders [84]. }\end{array}$ & $\begin{array}{l}\text { Fails to address boundaries as identified by local } \\
\text { participants - although GPS can be used to } \\
\text { counter-act this and geo-reference point data. } \\
\text { Difficult to include all intricate details of } \\
\text { local knowledge. } \\
\text { Translation of community boundaries onto maps } \\
\text { using GIS is often inadequate for spatial analysis. }\end{array}$ \\
\hline
\end{tabular}


Table 3. Cont.

\begin{tabular}{|c|c|c|c|}
\hline \multicolumn{4}{|c|}{ Participatory Planning and Techniques } \\
\hline No & Methodology & Strengths & Limitations \\
\hline 7 & $\begin{array}{l}\text { Process } \\
\text { Framework } \\
{[73,74] .}\end{array}$ & $\begin{array}{l}\text { Assists community members to identify and relate to changing } \\
\text { vulnerability patterns over time and how their activities could have } \\
\text { contributed to this. } \\
>\text { Encourages a proactive response amongst community members to } \\
\text { address their own vulnerability. } \\
>\text { Uses available knowledge therefore identifying options which can be } \\
\text { implemented by communities immediately to reduce their risk. } \\
\text { Provides a simple process which is easy to follow by community } \\
\text { members and easily managed. }\end{array}$ & $\begin{array}{l}\text { Accessibility of scientific information in a format } \\
\text { which local communities are able to understand } \\
\text { and use. } \\
\text { The process is facilitated by outsiders; these should } \\
\text { preferably be local people for an understanding of the } \\
\text { local context. } \\
\text { As with all participatory techniques there is a risk of } \\
\text { introducing facilitator bias rather than enabling } \\
\text { community members to reach decisions and } \\
\text { consensus based on an exploration of their situation. } \\
\text { Concrete tools or methods are not provided for } \\
\text { building trust between stakeholders [70]. }\end{array}$ \\
\hline 8 & $\begin{array}{l}\text { Scenario } \\
\text { Planning [85]. }\end{array}$ & $\begin{array}{l}\text { Scenario models are flexible, transparent and able to use narrative to } \\
\text { describe possible futures in all their complexity. } \\
>\text { Suited to engagement with stakeholders without scientific backgrounds. } \\
\text { Scenarios can integrate knowledge and underlying epistemologies of } \\
\text { different actors [75]. } \\
\text { Comprised of information at multiple scales, scenarios help to identify } \\
\text { drivers of change that are both exogenous and endogenous to the system } \\
\text { of interest. } \\
\text { Scenarios can be used to evaluate knowledge by (a) indicating where } \\
\text { knowledge needs to be updated as new information is available or } \\
\text { perceptions change; (b) assessing the relevance and credibility of } \\
\text { scientific knowledge and (c) revisiting assumptions underpinning } \\
\text { scenarios. } \\
\text { Scenario planning provides a mechanism for integrating knowledge } \\
\text { temporally (into the future) as well as spatially. }\end{array}$ & $\begin{array}{l}\text { Scenarios do not integrate knowledge explicitly, but } \\
\text { rather implicitly through building stories based on } \\
\text { different information sources [75]. } \\
\text { Scenarios risk being a 'knowledge dump', whereby } \\
\text { issues of accuracy and precision, weighting, } \\
\text { standardization and resolution of discrepancies do not } \\
\text { often receive attention [75]. } \\
\text { Scenarios developed are qualitative - maybe useful to } \\
\text { develop both quantitative and qualitative scenarios } \\
\text { for further analysis. } \\
\text { There is often a trade off between giving too little } \\
\text { information to enable participants to analyse future } \\
\text { scenarios and giving too much information thereby } \\
\text { introducing a bias. } \\
\text { Ample space and time is necessary to accommodate } \\
\text { differences in opinion and to reach consensus. }\end{array}$ \\
\hline
\end{tabular}


Gap 2: EbA is a modern term yet a wealth of past knowledge and actions have not been integrated into adaptation.

Expanding the term's scope would be useful for drawing on past work which may have incorporated local and external knowledge. Since EbA is a modern term, applying it would benefit from building upon the vast literature available on 'ecosystem-based management' and 'ecosystem management', the breadth and depth of which is often not fully considered in contemporary approaches. The use of the term EbA as a 'buzzword' may suitably contribute to accessing available funds, yet organisations need to be mindful of literature and experiences developed prior to the introduction of the term ' $\mathrm{EbA}^{\prime}$ ' and how local and external knowledge were incorporated within this. Recognising past contributions, and improving them, can assist in filling in other gaps in EbA and in identifying options for knowledge integration.

Gap 3: Work and studies on Caribbean SIDS focus upon coastal and offshore marine ecosystems, not highlighting the diverse range of ecosystems present within Caribbean SIDS, especially inland.

One significant area for improvement regarding EbA in Caribbean SIDS is that, whether specifically termed EbA or more generally termed CCA (which incorporates ecosystems), coastal and off shore marine ecosystems dominate the discussion. That is not unreasonable for SIDS. Yet SIDS also have inland ecosystems which should be part of EbA [86], especially since all ecosystems are tightly linked in small islands. As an example, coastal communities in Haiti experience exacerbated floods due to deforestation upstream [87]. Consequently, successful EbA along the coast would necessitate management of upland forest ecosystems. In turn this would require building upon the knowledge of local communities upstream and downstream in addition to relevant and applicable external knowledge. Further research regarding the diverse range of ecosystems in Caribbean SIDS and their interaction, alongside the identification of applicable local and external knowledge to facilitate the development of $\mathrm{EbA}$ is essential for developing $\mathrm{EbA}$ strategies, even for a coastal location.

Lesson 1: There is a need to identify and highlight information on local and external knowledge for $E b A$.

From such discussion, one overall lesson is that specifics on what does and does not exist regarding local and external knowledge for $\mathrm{EbA}$ are often lacking, instead lapsing into relatively generic descriptions of enacting EbA or community consultation. The ten methodologies reviewed in Section 4 go some way towards identifying 'how' to integrate local and external knowledge for action on the ground, with the references given often detailing step-by-step methods and providing raw data which are then analysed step-by-step. That provides a starting point for new projects, since any method would need to be contextualised for the community in which EbA is being implemented. In many cases, though, quite rightly, EbA activities are often not differentiated from non-EbA activities, instead recognising EbA as part of wider CCA processes and CCA as part of wider development processes.

Recognising these wider processes is important for engaging local people. Most people living in the Caribbean SIDS tend to have immediate life and livelihood concerns including health, water, and food. Thus, it can be challenging to engage them in EbA (or other development) projects on the basis of long-term benefits. Instead, some immediate gains need to be demonstrated. To show that, thereby encouraging community engagement, small-scale demonstration projects incorporating local and 
external knowledge with explicit, immediate benefits can be helpful. Examples to emulate are from a pilot project in Jamaica [66] and a full-scale project in Samoa [57].

Lesson 2: Use local champions.

EbA initiatives would also benefit from local champions. As MSV does and as is done within wider DRR, initiatives involving local community members can sometimes be enhanced by resident champions who promote the project, thereby generating enthusiasm within the community [88]. Local champions can be key to initiating and encouraging community engagement, educating community members and establishing links amongst community members, local government and other stakeholders to facilitate uptake of project ideas, integration of local and external knowledge and continuity of any intervention.

\section{Lesson 3: Draw upon past development experience.}

EbA initiatives should draw on past development experience, such as from protected area implementation, to better identify and resolve competing interests and goals within the community [89]. Frequently, false assumptions exist that communities are homogenous or that local knowledge is one coherent entity $[65,90]$. Instead, many different sectors hold different viewpoints and goals do not always align, especially regarding the integration of knowledge. Many of the techniques discussed in Section 4 are designed to air differing opinions, especially from minorities, so that perspectives can be acknowledged and integrated into final actions as best as feasible, usually with compromises required from all parties.

\section{Lesson 4: Regular monitoring and evaluation is required.}

The success of these approaches and of EbA and CCA more widely, requires on-going monitoring and evaluation focused upon the successes and challenges of approaches used to integrate local and external knowledge. Given how frequently $\mathrm{EbA}$ is mentioned without fully describing it, it is particularly important to determine how effective it is to just mention 'ecosystems' in project or program activity compared to detailing the ecosystems involved, the knowledge available and how this can contribute to CCA and wider development activities. Monitoring and evaluation require both internal and external input; that is, both locals and non-locals should be involved, providing their own observations and interpretations. Consequently, monitoring and evaluation to ensure effectiveness and continuity of any EbA work, needs to combine local and external knowledge, returning to the baseline of one of the main principles of successful EbA.

\section{Conclusions: Promoting EbA in the Caribbean and Further Afield}

From this review of EbA in Caribbean SIDS, focusing on the integration of local and external knowledge, three main ways forward are suggested to address the identified gaps for EbA in Caribbean SIDS and potentially further afield.

First and foremost, there is a need to design more encompassing, more locally-based processes to integrate EbA with existing mechanisms and approaches for CCA in Caribbean SIDS communities. Research would involve further field testing and refinement of EbA approaches which explicitly integrate local and external knowledge in selected communities and for a diverse range of ecosystems are required in order to scale up successful EbA initiatives. Since Caribbean SIDS are diverse, an exciting opportunity exists to compare and contrast across locations which would help to indicate how contexts and local distinctiveness lead to different outcomes. That would provide scientific backing to 
identify good-practice case studies in Caribbean SIDS, indicating where problems resulted so that those problems could be solved would be a useful contribution to the scientific literature and for policy advice regarding knowledge integration.

In many instances, an important lesson is that relatively simple interventions, even in the form of networking and information/story sharing, can result in beneficial results [91]. Innovation should be promoted, but newness is not always a criterion to ensure that EbA integrating local and external knowledge works adequately. Often, a 'back to basics' approach-especially regarding the long history of knowledge on ecosystem management - involving all actors can yield solid results for EbA. Much earlier research has been neglected or forgotten, yet is now being made available [92], providing a resource for building on the past scientific foundation to extend research today.

The second way forward is to enhance information sharing across ecosystems and communities to ensure local and external knowledge is available in usable formats for all stakeholders. The cataloguing of knowledge and an assessment of knowledge efficacy in addressing climate change impacts would significantly enhance the development and subsequent implementation of EbA strategies. Methods need to be researched, piloted, and published before implementing them full-scale in practice.

Establishing strong 'inter-community' and 'inter-island' networks and exchanges to foster knowledge building and sharing on EbA would contribute to the identification and cataloguing of beneficial local knowledge for EbA. Furthermore, the quantitative and qualitative evaluation of any approach implemented would enable lessons to be learnt and applied so that transferrable aspects of good practices could be replicated across other ecosystems and in other Caribbean SIDS.

The third way forward is to empower communities to act. There is a need to implement known means by which communities can enact $\mathrm{EbA}$ for themselves and access external knowledge across diverse ecosystems in Caribbean SIDS. The planning, development and implementation of a training-of-trainers programme promoting 'community-to-community' learning and exchange for EbA would contribute to an evidence base to support integrating local and external knowledge in Caribbean SIDS.

The development of research and practice tools, materials and guidance on incorporating ecosystem-based approaches integrating local and external knowledge into adaptation planning (or policies and structures) at local and national levels would enhance linkages with wider governance processes. These need to be specific and to discuss contextuality better than most current work. That is one need within research, in terms of more studies which select a specific case site, tailor methods to that site's contextuality, and compare the contextualisation across different sites in order to glean an understanding on what site characteristics lead to similarities and differences for EbA. The applicability and relevance of such approaches should be demonstrated through using simple impact measurement indices at the local level. These should be developed and designed as applied research projects in partnership with communities in order to measure the success of EbA approaches integrating local and external expertise.

A coordination entity already exists in the form of the CCCCC which could take leadership. Whilst the CCCCC is an excellent coordination body, well representing the Caribbean region for climate change topics, there is sometimes limited mention of community consultation, or of specific mechanisms for community consultation, in developing large regional projects focusing on CCA and 
community benefits. Undertaking an in-depth analysis of EbA interventions integrating local and external knowledge would highlight the importance of EbA approaches and their ability to address climate change impacts, whilst situating them within wider CCA and development processes within Caribbean SIDS and beyond.

\section{Conflict of Interest}

The authors declare no conflict of interest.

\section{References}

1. Small Island Developing States Network. Available online: http://www.sidsnet.org (accessed on 17 August 2012).

2. Pelling, M.; Uitto, J.I. Small island developing states: Natural disaster vulnerability and global change. Environ. Hazards 2001, 3, 49-62.

3. Kelman, I. Hearing local voices from Small Island Developing States for climate change. Local Environ. 2010, 15, 605-619.

4. Lewis, J. Development in Disaster-Prone Places: Studies of Vulnerability; Intermediate Technology Publications: London, UK, 1999.

5. Pulwarty, R.S.; Nurse, L.A.; Trotz, U.O. Caribbean Islands in a changing climate. Environ. Sci. Policy Sustain. Dev. 2010, 52, 16-27.

6. IPCC. IPCC Fourth Assessment Report; Intergovernmental Panel on Climate Change: Geneva, Switzerland, 2007.

7. Vignola, R.; Locatelli, B.; Martinez, C.; Imbach, P. Ecosystem-based adaptation to climate change: What role for policy-makers, society and scientists? Mitig. Adapt. Strat. Global Change 2009, 14, 691-696.

8. Millennium Ecosystem Assessment (MEA). Ecosystems and Human Well-Being: Synthesis; Island Press: Washington, DC, USA, 2005.

9. Secretariat of the Convention on Biological Diversity. Connecting Biodiversity and Climate Change Mitigation and Adaptation: Report of the Second Ad Hoc Technical Expert Group on Biodiversity and Climate Change; CBD Technical Series No. 41; Secretariat of the Convention on Biological Diversity: Montreal, PQ, Canada, 2009.

10. Burke, L.; Maidens, J.; Spalding, M.; Kramer, P.; Green, E.; Greenhalgh, S.; Nobles, H.; Kool, J. Reefs at Risk in the Caribbean; World Resources Institute: Washington, DC, USA, 2004.

11. Andrade Pérez, A.; Herrera Fernandez, B.; Cazzolla Gatti, R. Building Resilience to Climate Change: Ecosystem Based Adaptation and Lessons from the Field; IUCN: Gland, Switzerland, 2010; pp. 15-16.

12. Spehn, E. Mountain Biodiversity: Effects of Climate Change and How to Manage Them; Sustainable Mountain Development 60, ICIMOD: Kathmandu, Nepal, 2004.

13. Racey, G.D. Preparing for Change: Climate Change and Resource Management in Northwest Region, NWSI Technical Workshop Report TWR-04; Northwest Science and Information: Thunder Bay, ON, Canada, 2005.

14. IUCN. IUCN Caribbean Initiative: Programme for 2009-2012; IUCN: Gland, Switzerland, 2008.

15. Slocombe, D.S. Ecosystem-based management. BioScience 1993, 43, 612-622. 
16. Database on ecosystem-based approaches to adaptation. Available online: http://unfccc.int/ adaptation/nairobi_work_programme/knowledge_resources_and_publications/items/6227txt.php (accessed on 17 August 2012).

17. Andrade, A.; Cordoba, R.; Dave, R.; Girot, P.; Herrera, F.B.; Munroe, R.; Oglethorpe, J.; Paaby, P.; Pramova, E.; Watson, J.; Vergara, W. Draft Principles and Guidelines for Integrating Ecosystem-Based Approaches to Adaptation in Project and Policy Design: A Discussion Document; Centro Agronomico Tropical de Investigacion y Ensenanza (CATIE): Turrialba, Costa Rica, 2011.

18. Mercer, J. Knowledge and Disaster Risk Reduction. In The Routledge Handbook of Hazards and Disaster Risk Reduction; Wisner, B., Gaillard, J.C., Kelman, I., Eds.; Routledge: London, UK, 2011; pp. 89-100.

19. Watts, R.J.; Richter, B.D.; Opperman, J.J.; Bowmer, K.H. Dam reoperation in an era of climate change. Mar. Freshwater Res. 2011, 62, 321-327.

20. Opperman, J.J.; Galloway, G.E.; Fargione, J.; Mount, J.F.; Richter, B.D.; Secchi, S. Sustainable floodplains through large-scale reconnection to rivers. Science 2009, 326, 1487-1488.

21. Falkenburg, L.J.; Burnell, O.W.; Connell, S.D.; Russell, B.D. Sustainability in near-shore marine systems: Promoting natural resilience. Sustainability 2010, 2, 2593-2600.

22. Kerr, S.A. What is Small Island Sustainable Development about? Ocean Coast. Manage. 2005, 48, 503-524.

23. McConney, P.; Mahon, R. Size matters: Scaling management and capacity to achieve sustainability in SIDS. FAO Fish. Rep. 2005, 782, 293-306.

24. McGillivray, M.; Naudé, W.; Santos-Paulino, A.U. Policy arena: Small island states development challenges: Introduction. J. Int. Dev. 2010, 20, 481-485.

25. Sillitoe, P. The development of indigenous knowledge. Curr. Anthropol. 1998, 39, 223-252.

26. UNEP. Climate Change in the Caribbean and the Challenge of Adaptation; United Nations Environment Programme: Regional Office for Latin America and the Caribbean, Panama City, Panama, 2008.

27. Graci, S.; Dodds, R. Sustainable Tourism in Island Destinations; Earthscan: London, UK, 2010.

28. Bueno, R.; Herzfeld, C.; Stanton, E.A.; Ackerman, F. The Caribbean and Climate Change: The Costs of Inaction; Stockholm Environment Institute and Global Development and Environment Institute, Tufts University: Medford, MA, USA, 2008.

29. Wege, D.C.; Ryan, D.; Varty, N.; Anadón-Irizarry, V.; Pérez-Leroux, A. Ecosystem Profile: The Caribbean Islands Biodiversity Hotspot; BirdLife International, Critical Ecosystem Partnership Fund: Washington, DC, USA, 2009.

30. IFAD. Rural Poverty Report 2011; IFAD (International Fund for Agricultural Development): Rome, Italy, 2010.

31. Munang, R.T.; Thiaw, I.; Rivington, M. Ecosystem management: Tomorrow's approach to enhancing food security under a changing climate. Sustainability 2011, 3, 937-954.

32. Richardson, R.B. Ecosystem services and food security: Economic perspectives on environmental sustainability. Sustainability 2010, 2, 3520-3548. 
33. Medeiros, D.; Hove, H.; Keller, M.; Echeverría, D.; Parry, J.E. Review of Current and Planned Adaptation Action: The Caribbean. Available online: http:/www.adaptationpartnership.org /resource/caribbean-current-and-planned-adaptation-action (accessed on 17 August 2012).

34. United Nations Framework Convention on Climate Change (UNFCCC). Ecosystem-Based Approaches to Adaptation: Compilation of Information; UNFCCC: Bonn, Germany, 2011.

35. CCCCC. Climate Change and the Caribbean: A Regional Framework for Achieving Development Resilient to Climate Change; CCCCC: Belmopan, Belize, 2009.

36. Salm, R.V.; Clark, J.R.; Siirila, E. Marine and Coastal Protected Areas: A Guide for Planners and Managers, 3rd ed.; IUCN: Gland, Switzerland, 2010.

37. Climate Investment Funds. Available online: http://www.climateinvestmentfunds.org/cif/ppcr (accessed on 17 August 2012).

38. Saint Lucia Strategic Programme for Climate Resilience. Available online: http://www. climateinvestmentfunds.org/cif/sites/climateinvestmentfunds.org/files/PPCR\%204\%20SPCR\%20 St.\%20Lucia.pdf (accessed on 29 February 2012).

39. European Union Jamaica Project Sheet. Available online: http://eeas.europa.eu/delegations/ jamaica/documents/eu_jamaica/climate_change_adaption_en.pdf (accessed on 7 March 2012).

40. BirdLife International. Partners with Nature: How Healthy Ecosystems are Helping the World's Most Vulnerable Adapt to Climate Change; BirdLife International: Zeist, The Netherlands, 2010.

41. WWF. WWF Adaptation Case Studies for Responding to Climate Change Impacts; WWF: Buenos Aires, Argentina, 2009.

42. Wisner, B. Bridging "expert" and "local" knowledge for counter-disaster planning in urban South Africa. Geojournal 1995, 37, 335-348.

43. Shaw, R.; Sharma, A.; Takeuchi, Y. Indigenous Knowledge and Disaster Risk Reduction: From Practice to Policy; Nova Science Publishers: New York, NY, USA, 2009.

44. Gupta, A.K.; Nair, S.S. Ecosystem Approach to Disaster Risk Reduction; National Institute of Disaster Management: New Delhi, India, 2012.

45. Kelman, I.; Gaillard, J.C. Embedding Climate Change Adaptation within Disaster Risk Reduction. In Climate Change Adaptation and Disaster Risk Reduction: Issues and Challenges; Shaw, R., Pulhin, J.M., Pereira, J.J., Eds.; Emerald Books: Bedfordshire, UK, 2010; pp. 23-46.

46. Nunn, P.D.; Hunter-Anderson, R.; Carson, M.T.; Thomas, F.; Ulm, S.; Rowland, M.J. Times of plenty, times of less: Last-millennium societal disruption in the pacific basin. Hum. Ecol. 2007, 35, 385-401.

47. Kelman, I.; Lewis, J.; Gaillard, J.C.; Mercer, J. Participatory action research for dealing with disasters on islands. Island Studies J. 2011, 6, 59-86.

48. Woodward, E.; Jackson, S.; Finn, M.; McTaggart, P.M. Utilising Indigenous seasonal knowledge to understand aquatic resource use and inform water resource management in northern Australia. Ecol. Manage. Restor. 2012, 13, 58-64.

49. Lertzman, D.A. Best of two worlds: Traditional ecological knowledge and Western science in ecosystem-based management. BC J. Ecosyst. Manage. 2010, 10, 104-126.

50. Lefale, P.F. Ua 'afa le Aso Stormy weather today: Traditional ecological knowledge of weather and climate. The Samoa experience. Climatic Change 2010, 100, 317-335. 
51. Speranza, C.I.; Kiteme, B.; Ambenje, P.; Wiesmann, U.; Makali, S. Indigenous knowledge related to climate variability and change: Insights from droughts in semi-arid areas of former Makueni District, Kenya. Climatic Change 2010, 100, 295-315.

52. Orlove, B.; Roncoli, C.; Kabugo, M.; Majugu, A. Indigenous climate knowledge in southern Uganda: The multiple components of a dynamic regional system. Climatic Change 2010, 100, 243-265.

53. King, D.N.T.; Skipper, A.; Tawhai, W.B. Māori environmental knowledge of local weather and climate change in Aotearoa-New Zealand. Climatic Change 2008, 90, 385-409.

54. Mann, A. Riders under storms: Contributions of nomadic herders' observations to analysing climate change in Mongolia. Global Environ. Change 2010, 20, 162-176.

55. Wajih, S.A. Traditional Environmental Wisdom and Disaster Risk Reduction: Experiences from Terai Of Eastern Uttar Pradesh. In Ecosystem Approach to Disaster Risk Reduction; Gupta, A.K., Nair, S.S., Eds.; National Institute of Disaster Management: New Delhi, India, 2012; pp. 57-64.

56. Krishnamurthy, P.K.; Fisher, J.B.; Johnson, C. Mainstreaming local perceptions of hurricane risk into policymaking: A case study of community GIS in Mexico. Global Environ. Change 2011, $21,143-153$.

57. Daly, M.; Poutasi, N.; Nelson, F.; Kohlhase, J. Reducing the climate vulnerability of coastal communities in Samoa. J. Int. Dev. 2010, 22, 256-281.

58. Mavrogenis, S.; Kelman, I. Community-Based Adaptation Tools in SIDS: Field Work Experience from Tonga, Proceedings of the Planet Under Pressure, London International Convention Centre, London, UK, 26-29 March 2012.

59. Jupiter, S. Adaptive Ecosystem Management to Improve Resilience to Climate Change in Fiji. In Draft Principles and Guidelines for Integrating Ecosystem-Based Approaches to Adaptation in Project and Policy Design: A Discussion Document.; Andrade, A., Cordoba, R., Dave, R., Girot, P., Herrera, F.B., Munroe, R., Oglethorpe, J., Paaby, P., Pramova, E., Watson, J., Vergara, W., Eds.; Centro Agronomico Tropical de Investigacion y Ensenanza (CATIE): Turrialba, Costa Rica, 2011.

60. World Bank. Convenient Solutions to an Inconvenient Truth: Ecosystem-Based Approaches to Climate Change; World Bank: Washington, DC, USA, 2009.

61. Mercer, J.; Dominey-Howes, D.; Kelman, I.; Lloyd, K. The potential for combining indigenous and western knowledge in reducing vulnerability to environmental hazards in small island developing states. Environ. Hazards 2007, 7, 245-256.

62. Many Strong Voices. Available online: www.manystrongvoices.org (accessed on 17 August 2012).

63. Exchange for Local Observations and Knowledge of the Arctic. Available online: http://elokaarctic.org (accessed on 16 August 2012).

64. Huntington, H.P. Arctic science: The local perspective. Nature 2011, 478, 182-183.

65. Bankoff, G.; Freks, G.; Hilhorst, D. Mapping Vulnerability: Disasters, Development \& People; Earthscan: London, UK, 2004.

66. United Nations Environment Programme (UNEP). Risk and Vulnerability Assessment Methodology Development Project (RiVAMP): Linking Ecosystems to Risk and Vulnerability Reduction the Case of Jamaica; UNEP: Geneva, Switzerland, 2010. 
67. Armitage, D.; Marschkeb, M.; Plummer, R. Adaptive co-management and the paradox of learning. Global Environ. Change 2008, 18, 86-98.

68. Armitage, D.R.; Plummer, R.; Berkes, F.; Arthur, R.I.; Charles, A.T.; Davidson-Hunt, I.J.; Diduck, A.P.; Doubleday, N.C.; Johnson, D.S.; Marschke, M.; et al. Adaptive co-management for social-ecological complexity. Front. Ecol. Environ. 2009, 7, 95-102.

69. Cullen-Unsworth, L.C.; Hill, R.; Butler, J.R.A.; Wallace, M. A research process for integrating Indigenous and scientific knowledge in cultural landscapes: Principles and determinants of success in the Wet Tropics World Heritage Area, Australia. Geogr. J. 2011, doi: 10.1111/j.14754959.2011.00451.x.

70. Cadag, J.R.D.; Gaillard, J.C. Integrating knowledge and actions in disaster risk reduction: The contribution of participatory mapping. Area 2012, 44, 100-109.

71. Kumar, S. Methods for Community Participation: A Complete Guide for Practitioners; ITDG Publishing: Warwickshire, UK, 2002.

72. Corbett, J.; Rambaldi, G.; Kyem, P.; Weiner, D.; Olson, R.; Muchemi, J.; McCall, M.; Chambers, R. Overview: Mapping for Change: The Emergence of a New Practice. In Participatory Learning and Action 54, 13-19 Special Issue on: Mapping for Change: Practice, Technologies and Communication; Proceedings of the International Conference on Participatory Spatial Information Management and Communication PGIS '05-KCCT, Nairobi, Kenya, 7-10 September 2005; IIED: London, UK, 2006.

73. Mercer, J.; Kelman, I.; Taranis, L.; Suchet-Pearson, S. Framework for integrating indigenous and scientific knowledge for disaster risk reduction. Disasters 2010, 34, 214-239.

74. Kelman, I.; Mercer, J.; West, J. Combining indigenous and scientific knowledge for community-based climate change adaptation and mitigation. PLA 2009, 60, 41-53.

75. Bohensky, E.L.; Butler, J.R.A.; Mitchell, D. Scenarios for knowledge integration: Exploring ecotourism futures in Milne Bay, Papua New Guinea. J. Mar. Bio. 2011, doi:10.1155/ 2011/504651.

76. Country in the Spotlight: Some Lessons from Post-Disaster Response-Suriname. Available online: http://www.undp.org.cu/crmi/docs/undp-surpostdresp-bp-2007-en.pdf (accessed on 29 February 2012).

77. Armah, F.A.; Yawson, D.O.; Pappoe, A.N.M.; Afrifa, E.K.A. Participation and sustainable management of coastal lagoon ecosystems: The case of the Fosu lagoon in Ghana. Sustainability 2010, 2, 383-399.

78. Armitage, D.; Berkes, F.; Dale, A.; Kocho-Schellenberg, E.; Patton, E. Co-management and the co-production of knowledge: Learning to adapt in Canada's Arctic. Global Environ. Change 2011, 21, 995-1004.

79. Rambaldi, G.; Callosa-Tarr, J. Participatory 3-Dimensional Modelling: Guiding Principles and Applications; ASEAN Regional Centre for Biodiversity Conservation: Los Baños, Laguna, Philippines, 2002.

80. Cooke, B.; Kothari, K. Participation: The New Tyranny?; Zed Books: London, UK, 2001.

81. Fabricius, C.; Scholes, R.; Cundill, G. Mobilizing Knowledge for Integrated Ecosystem Assessments. In Bridging Scales and Knowledge Systems: Concepts and Applications in 
Ecosystem Assessment; Reid, W., Berkes, F., Wilbanks, T.J., Capistrano, D., Eds.; Millennium Ecosystem Assessment and Island Press: Washington, DC, USA, 2006; Chapter 9.

82. Payton, R.W.; Barr, J.J.F.; Martin, A.; Sillitoe, P.; Deckers, J.F.; Gowing, J.W.; Hatibu, N.; Naseem, S.B.; Tenywag, M.; Zuberi, M.I. Contrasting approaches to integrating indigenous knowledge about soils and scientific soil survey in East Africa and Bangladesh. Geoderma 2003, $111,385-386$.

83. McCall, M.K.; Minang, P.A. Assessing participatory GIS for community-based natural resource management: Claiming community forests in Cameroon. Geogr. J. 2005, 171, 340-356.

84. Aswani, S.; Lauer, M. Incorporating fishermen's local knowledge and behavior into geographical information systems (GIS) for designing marine protected areas in Oceania. Hum. Organ. 2006, 65, 81-102.

85. Van Asselt Marjolein, B.A.; Rijkens-Klomp, N. A look in the mirror: Reflection on participation in integrated assessment from a methodological perspective. Global Environ. Change 2002, 12, $167-184$.

86. Integrating Watershed and Coastal Areas Management (GEF-IWCAM). Available online: http://www.iwcam.org/media-centre/media-releases/gef-iwcam-final-project-conference-summar y/view (accessed on 29 February 2012).

87. Renwick, W.; Balthazar, S.L.; Boardman, M.R.; Hillaire, J.V.; Laviolette, L.L.; Primack, A.G.; Tardieu, J.F.; Eliacin, J. The Geomorphic Context of Flood Hazards in Haiti; American Geophysical Union, Spring Meeting 2005, Joint Assembly, Abstract \#H21D-06; American Geophysical Union: New Orleans, LA, USA, 2005.

88. Delica-Willison, Z.; Gaillard, J.C. Community Action and Disaster. In The Routledge Handbook of Hazards and Disaster Risk Reduction; Wisner, B., Gaillard, J.C., Kelman, I., Eds.; Routledge: London, UK, 2011; pp. 711-722.

89. Duda, A.M.; Sherman, K. A new imperative for improving management of large marine ecosystems. Ocean Coast. Manage. 2002, 45, 797-833.

90. Walmsley, J. The nature of community: Putting community in place. Dialogue 2006, 25, 5-12.

91. Caribbean Risk Management Initiative (CRMI). Available online: http://www.undp.org.cu /crmi/docs/crmi-eval-cr-2008-en.pdf (accessed on 28 February 2012).

92. The UNESCO/UNFPA Population and Environment Project in the Eastern Islands of Fiji, Man and the Biosphere Programme, 1974-1976. Available online: http://www.islandvulnerability.org/ mabfiji.html (accessed on 06 August 2012).

(C) 2012 by the authors; licensee MDPI, Basel, Switzerland. This article is an open access article distributed under the terms and conditions of the Creative Commons Attribution license (http://creativecommons.org/licenses/by/3.0/). 